\title{
Revisiting the Benefits of High School Accounting to Increase the Number of Accounting Majors
}

\author{
Edward E. Scott \\ Slippery Rock University \\ S. Cathy McCrary \\ Georgia Gwinnett College
}

In recent years, there has been concern surrounding the future supply of accounting graduates due to declining accounting program enrollment. This exploratory study investigates which undergraduate class year is likely better suited for increased efforts by accounting faculty to influence students' decisions to major in accounting, particularly students who studied accounting in high school. Using variables from a prior study that conceptualized an integrative theoretical model based on social cognitive career theory and the theory of reasoned action, we examine the potential effect that precollege coursework in accounting might have on students' personal interest, accounting technical skills self-efficacy, image of the accounting profession, and intent to major in accounting. Undergraduate business students enrolled in core business courses were surveyed and high school students participated in focus group discussions. Study results indicate differences between groups of students who did (did not) study accounting in high school and suggest freshmen year is influential towards intent to major in accounting.

Keywords: accounting major, accounting curricula, personal interest, self-efficacy, theory of reasoned action, social cognitive career theory

\section{INTRODUCTION}

During the past fifteen years, scholars have used the theory of reasoned action (Felton, et al., 1995; Law, 2010) and social cognitive career theory (Lent et al., 1994, 2002) to examine how social and psychological variables (e.g., self-efficacy and personal interest) affect students' decisions to major in accounting. This exploratory study investigates whether these variables differentially affect personal interest in accounting, accounting technical skills self-efficacy, image of the accounting profession, and intent to major in accounting between students who did (did not) take accounting in high school. Moreover, this study investigates differences between groups of students during their freshmen and sophomore years in college.

The aim of this study is to determine which class year might be better suited for increased efforts by accounting faculty to influence students' intent to major in accounting, particularly students who completed a high school accounting course. This study is relevant to accounting educators since enrollment in undergraduate accounting programs may be trending downward like what is being experienced by the 
public university involved in this study (and its 13 sister schools within a state system of higher education). Accordingly, initiatives to increase accounting program enrollment are necessary.

Gabbin (2019) voiced concern about the future supply of accounting graduates based on declining accounting program enrollment. Although the reasons for declining enrollments vary by school, we propose that one aspect of many accounting programs should be reevaluated by schools experiencing a decline in accounting majors. The introductory accounting course is commonly taken during the sophomore year with the rationale that freshmen need time to adjust to the college experience. Indeed, accounting is a challenging course for some students and requiring them to study accounting during their freshmen year might set some students up for failure.

Yet, we speculate that this rationale might impede the progression of students' personal interest in accounting, particularly students who studied accounting in high school who might not want to wait until their sophomore year to take the first college accounting course. Although careful analysis on a programby-program basis is necessary before implementing major changes, providing students with an opportunity to study accounting during their freshmen year might prove advantageous. Specifically, such a change would align with The Pathways Commission on Accounting Higher Education objectives (Behn et al., 2012) for improving accounting education on four fronts.

First, there is the likelihood of leveraging students' personal interest in accounting - especially if first piqued in high school - to influence them to declare accounting as a major during their freshmen year. Second, if students who took accounting in high school also take accounting as freshmen, they could potentially benefit from a smoother transition to college accounting due to reinforcement of accounting concepts and procedures learned in high school. Third, some accounting programs compress two courses, Accounting Principles I and II, into one Financial Accounting course required for all business majors.

Consequently, the Financial Accounting course becomes a condensed survey course requirement for business students which might be disadvantageous for accounting majors and minors who need a thorough, rigorous study of foundational accounting principles to prepare for higher level accounting courses. For example, the Intermediate Accounting course has increased in complexity and requires more instructional time due to new accounting guidance causing some schools to add a third intermediate course.

Finally, if students - particularly those who studied accounting in high school and intend to major in accounting - complete two intermediate accounting courses by the end of their sophomore year, they might become more competitively positioned for the internship application process. Thereby, increasing their likelihood for full-time employment offers as they approach graduation.

In this study, we revisit the effect of studying accounting in high school on students' intent to major in accounting. Specifically, we examine differences between six groups of undergraduate business students: freshmen who did (did not) study accounting in high school, sophomores who did (did not) study accounting in high school, and freshmen/sophomores combined who did (did not) study accounting in high school. Preliminary findings suggest freshmen year is influential towards intent to major in accounting, taking high school accounting positively affects personal interest in the accounting profession, and students who study accounting in high school are more likely to major in accounting.

\section{LITERATURE REVIEW}

\section{Effects of High School Accounting on Success in Undergraduate Accounting Courses}

Several years have passed since researchers first examined the effects of high school accounting on student success in undergraduate accounting programs. Early research on the association between high school accounting and undergraduate accounting education at U.S. colleges and universities focused on how high school accounting affected students' performance in undergraduate accounting courses. Smith (1968) conducted an experimental study that included one control group of 20 randomly selected students who had not studied accounting in high school and two groups of 20 randomly selected students who studied accounting in high school. Smith (1968) found that students who studied high school accounting did not require the same amount of classroom instruction and had a stronger comprehension of course material by the end of the semester. 
Jacoby (1976) found that in the first undergraduate accounting course, 35 students who studied accounting in high school initially outperformed 90 students who did not study accounting in high school. As the course progressed however, the difference in performance between the two groups was not statistically significant (Jacoby, 1976). Baldwin and Howe (1982) investigated group differences based on academic performance in the first college accounting course and drop-out patterns. Their study did not find statistically significant differences between groups and suggested that students who studied accounting in high school: (a) appeared overly confident at the beginning of the course; (b) outperformed students who did not study accounting on the first exam; (c) tended to perform worse due to poor adjustment to the demands of the course as the course increased in complexity.

Swanson and Brooks (1984) considered twelve factors that may have affected group level differences in academic performance between students who studied accounting in high school compared to students who did not. Their research found that students who studied accounting in high school had higher grades in the first university course in accounting. Schroeder (1985) reported that students who studied more than one accounting course in high school believed they were better prepared for college introductory and intermediate accounting courses as evidenced by higher grades and lower course dropout rates compared to students with no precollege accounting coursework.

Chen et al. (2005) used multi-discriminant analysis to examine how intrinsic values, initial earnings, long-term earnings, job market factors, cost/benefit ratio, exposure to accounting in high school, and overall experience in the first college accounting course contributed to students' decision to major in accounting. The researchers found that overall experience in the first university accounting course and high school accounting explained more than $62 \%$ of the discrimination for sophomores (Chen et al., 2005). Jones and Wright (2011) found that studying accounting in high school had a statistically significant effect on a student's intent to study accounting in college and a higher positive effect on course grade. In sum, the literature generally reports that students who studied accounting in high school outperformed their counterparts who had no precollege exposure to accounting.

\section{Theoretical Framework}

Early research on the effect of high school accounting on academic performance in college accounting courses was key since scholars found positive associations between these educational experiences. However, when addressing the problem of a decrease in accounting majors, accounting educators must consider how to increase students' personal interest in accounting and intent to major in accounting. Thus, it is necessary to investigate other factors that may influence a student's decision to choose accounting as a major.

During the past decade, scholars developed and tested research models that incorporated social cognitive career theory (Lent et al., 1994) or the theory of reasoned action (Djatej et al., 2015) to investigate factors affecting students' interests in accounting. Interestingly, the effect of high school accounting on students' interests in accounting was not considered in studies using these theoretical models.

Our study fills this literature gap with an exploratory investigation into whether studying accounting in high school affects undergraduate students' personal interest in accounting, self-efficacy to perform technical accounting work; image of the profession; and intent to major in accounting. The study performed by Djatej et al. (2015) is particularly relevant to the current study because it conceptualized an integrative theoretical model based on social cognitive career theory and the theory of reasoned action. The Djatej et al. (2015) theoretical model incorporated measures of personal interest in accounting, accounting technical skills self-efficacy, image of the accounting profession, and intent to major in accounting. Accordingly, we provide theoretical background for these variables and how they might be associated with the study of accounting in high school and students' decisions to major in accounting.

\section{Accounting Technical Skills Self-Efficacy (ATSE)}

ATSE measures a person's belief that they could perform accounting related work. Based upon the American Institute of Certified Public Accountants' (AICPA) accounting competencies, Djatej et al. (2015) conceptualized the latent ATSE construct, developed measurement items, and performed a confirmatory 
factor analysis that validated ATSE as a latent variable that might influence a student's personal interest in accounting.

High school and college students generally view accountants as individuals with strong mathematical aptitude. However, students tend to be unaware of other prerequisite skills to perform as a competent accountant. The AICPA's accounting competencies imply math skills within the broader category of analysis while judgment, communication, research, and understanding are noted as additional skills necessary for the successful practice of accounting. Examining how these skills affect one's ATSE, and consequently, one's personal interest in accounting, is a worthwhile pursuit since these skills may have broader appeal to students exploring various career fields. Furthermore, accounting educators might positively influence students by incorporating academic content that develops these skills. We contend that the earlier students recognize the importance of these skills and how they are interrelated, the greater likelihood of influencing students' intent to major in accounting.

\section{Image of the Accounting Profession}

Among college students, the image of the accounting profession is in flux as students ponder whether the benefits of a career in accounting are worth the long work hours and stress associated with an accounting career (Gabbin et al., 2019). High school students, however, might not have these conflicting perspectives about accounting as a career choice. Focus group discussions with high school juniors and seniors revealed students' awareness of the relevance of their accounting course evidenced by: (a) a belief that "debt is bad;" and (b) the importance of saving for the short and long-term.

Thus, it can be argued that highlighting the relevance of the accounting profession and enhancing financial literacy are indirect benefits of high school accounting. Additionally, these perceptions might be indicators of favorable images of the accounting profession and students' recognition of the benefits of accounting related knowledge. For undergraduate accounting programs with declining enrollments, students' positive referents to the value of accounting education might open the door for collaborative recruiting opportunities with high schools.

\section{Personal Interest in Accounting}

Personal interest in accounting refers to an individual's general feeling about accounting and the strength of their desire to invest time to learn about the subject. We agree that "in general, a higher personal interest and more positive attitude toward accounting is expected to be associated with a greater intention to pursue an accounting major, though the positive correlation may not be perfect and can be affected by other factors such as competing fields of study" (Djatej et al., 2015, pp. 62-63).

\section{METHOD}

This study was conducted at two schools: a public liberal arts college in northeast Georgia and a public comprehensive university in western Pennsylvania. The Institutional Review Boards of both institutions approved the research study. Survey participants included 150 undergraduate freshmen (68) and sophomore (82) business students enrolled in core business courses (e.g., economics, financial accounting, managerial accounting) required for an undergraduate business degree. The survey instrument is displayed in Appendix A.

Additionally, eight high school students enrolled in a high school accounting course participated in the study through focus group discussions. The focus group interview protocol is shown in Appendix B.

\section{Measures}

Personal Interest in Accounting (PERS) was measured using the 2-item scale developed by Djatej et al. (2015). The PERS items were: "For me to major in Accounting would be a bad idea or good idea;" and "For me to major in Accounting would be unpleasant or pleasant." All items were measured on a 7-point Likert-type scale (1=bad idea, $7=$ good idea) and (1=unpleasant and 7=pleasant). Participant responses were 
averaged into a composite score with higher scores indicating more personal interest in accounting. The internal consistency estimate (coefficient alpha) for scores on PERS was .86.

Accounting Technical Skills Self-Efficacy (ATSE) was measured using the 4-item scale developed by Djatej et al. (2015). Examples of the ATSE items included: "I am usually able to locate and extract relevant information from available resource materials." All items were measured on a 7-point Likert-type scale (1=strongly disagree; $7=$ strongly agree). Participant responses were averaged into a composite score with higher scores indicating a greater sense of self-efficacy to perform accounting work. The internal consistency estimate (coefficient alpha) for scores on ATSE was also .86.

Image of the Accounting Profession (IMAG) was measured using the 5-item scale developed by Djatej et al. (2015). Examples of the $I M A G$ items included: "Most people working in Accounting are geeky and nerdy," and "most people working in Accounting are boring to be around." All items were measured on a 7-point Likert-type scale ( $1=$ strongly disagree; 7=strongly agree). Participant responses were reverse coded and averaged into a composite score with higher scores indicating a stronger positive image of the accounting profession. The internal consistency estimate (coefficient alpha) for scores on IMAG was .88.

Intent to Major in Accounting (INT) was measured using the 1-item scale developed by Djatej et al. (2015). The INT item was: "Assuming I satisfy the requirements to major in Accounting, I intend/plan to major in Accounting." The item was measured on a 7-point Likert-type scale (1=unlikely, 7=likely). Higher scores indicate greater intent to major in accounting.

After dividing the sample population into six groups [(1) freshmen who did not study accounting in high school; (2) freshmen who did study accounting in high school; (3) sophomores who did not study accounting in high school; (4) sophomores who did study accounting in high school; (5) combined groups of freshmen and sophomores who did not study accounting in high school; and (6) combined groups of freshmen and sophomores who did study accounting in high school], we subjected group means to independent sample $t$-tests to determine whether group differences were statistically significant. We calculated Cohen's $d$ effect sizes to understand the potential magnitude of the differences between groups.

\section{RESULTS}

Our study examined whether students who did (did not) study accounting in high school differed based on personal interest in accounting (PERS), accounting technical skills self-efficacy (ATSE), image of the accounting profession (IMAG), and intent to major in accounting (INT). Descriptive statistics and correlations for each of the previously described measures are displayed in Table $\mathrm{C} 1$. Results for $t$-tests and effect sizes are displayed in Tables C2 through C5 for each of the four measures. Tables C1 through C5 appear in Appendix C.

\section{Personal Interest in Accounting (Table C2)}

Group means were statistically different between groups 1 and 2 and groups 5 and 6. Groups 2 and 6 represent students who studied accounting in high school, and we theorize the statistically significant differences between groups 1 and 2 and groups 5 and 6 are related to the precollege exposure to accounting experienced by groups 2 and 6 .

The effect sizes of -.56 (Groups 1 and 2) and -.45 (Groups 5 and 6) indicate that high school accounting might have a moderate (Durlak, 2009; Ferguson, 2009) influence on personal interest in accounting.

\section{Accounting Technical Skills Self-Efficacy (Table C3)}

Although group means within the accounting technical skills self-efficacy measure were not statistically significant at the $95 \%$ confidence level, the p-value of .06 related to the mean difference between groups 1 and 2 was statistically significant at the $90 \%$ confidence level. Given the exploratory nature of this study, the p-value of .06 coupled with the moderate effect size of -.47 indicate that further study is necessary to examine the relationship between the study of accounting in high school and its effect on accounting technical skills self-efficacy in college freshmen. 


\section{Image of the Accounting Profession (Table C4)}

The differences between group means for image of the accounting profession were not statistically significant requiring no further interpretation.

\section{Intent to Major in Accounting (Table C5)}

Group means were statistically different between groups 3 and 4 and groups 5 and 6 . Groups 4 and 6 represented students who studied accounting in high school. Thus again, we speculate that the higher level of intent to major in accounting was likely influenced by their precollege experience with accounting. The effect sizes of -.49 and -.42 indicate that high school accounting might have a moderate (Durlak, 2009; Ferguson, 2009) influence on intent to major in accounting.

\section{CONCLUSION}

\section{Implications for Undergraduate Accounting Programs}

This exploratory investigation examined potential differences associated with students' personal interest in accounting, accounting technical skills self-efficacy, image of the accounting profession, and intent to major in accounting. Specifically, we examined whether group differences exist between undergraduate freshmen and sophomores who did (did not) study accounting in high school. Findings suggest that personal interest in accounting and intent to major in accounting differ between freshmen who did (did not) study accounting in high school. These same results were found for combined groups of freshmen and sophomores who did (did not) study accounting in high school.

Although the causes for declining accounting program enrollment vary by school, one common contributing factor is the actual and estimated decline in high school graduates from 2013 through 2023 (Seltzer, 2016). One study estimates a one million student (or more than six percent) decline in public high school enrollment by 2028 (Barshay, 2018). Moreover, these estimated declines in high school enrollment do not reflect the impact of the COVID-19 pandemic. The probable negative effect of the pandemic coupled with estimated declines in high school enrollment, likely exacerbate the urgency for accounting educators to carefully consider opportunities for collaboration with high schools to increase undergraduate accounting program enrollment.

In 2012, the Pathways Commission on Accounting Higher Education recommended action items to enhance accounting education for the benefit of students, educators, and practitioners (Behn et al., 2012). To encourage an increase in undergraduate accounting program enrollment, we reiterate the following action items recommended by the Pathways Commission on Accounting Higher Education:

- Action Item 4.1.8: Craft a first course in accounting that reflects the possibilities and challenges of a vibrant profession.

- Action Item 5.1.2: Build on existing high school programs and effort to enhance accounting curriculum.

- Action Item 5.1.4: Map educational and career pathways in accounting.

- Action Item 5.1.6: Determine when and how students make career choices.

- Action Item 5.1.7: Encourage continued and expanded efforts to place role models and mentors in high school accounting or business classes.

- Action Item 5.2.1: Build on previous efforts regarding how the first course in accounting is designed and delivered.

- Action Item 5.4.2: Enlist current (college) accounting students and student organizations to help high school students accessing and completing financial aid applications, like the Volunteer Income Tax Assistance (VITA) program.

The current study contributes to the literature by providing insight regarding when and how students make career choice decisions (action item 5.1.6). This study also provides support for how early exposure to accounting related concepts (e.g., debt) promotes the relevance of the accounting profession (action item 4.1.8) particularly by increasing financial literacy among high school students. Overall, each action item is critical to enhance accounting education and thereby, expand the pipeline to the accounting profession. 
Further, our exploratory findings suggest that four action items (4.1.8; 5.1.4; 5.1.6; and 5.2.1) are likely most influential if promoted during the first college accounting course offered freshmen year.

\section{Limitations and Future Research}

The primary limitation of this study was a lower-than-expected sample size. Therefore, caution must be exercised to avoid generalizing findings from this exploratory work. Additionally, the findings warrant further investigation to validate relationships between the variables of interests based on a hypothesized theoretical model. Future research on the effect of high school accounting should consider differences based on race, gender, and first generation versus continuing generation students. Nevertheless, this exploratory study informs our understanding of which undergraduate class year might be most effective for increased efforts by accounting faculty to influence students' decisions to major in accounting.

\section{ACKNOWLEDGEMENTS}

The authors are grateful for the assistance of Penn Hills Senior High School for supporting our research. Particularly, School District Superintendent Nancy Hines, Principal Eric Kostic, and School Counselor Dr. Amy Alexander. Educating and caring for students requires significant effort and time. We appreciate the time you took out of your busy schedules to steer the authors through the study approval process and to facilitate focus group discussions with students. Thank you so much.

The authors wish to acknowledge Sharon Haworth for her constructive comments during the early drafts of this paper. Thank you, Sharon.

\section{REFERENCES}

Baldwin, B.A., \& Howe, K.R. (1982, July). Secondary-level study of accounting and subsequent performance in the first college course. Accounting Review, pp. 619-626.

Barshay, J. (2018). The number of public school students could fall by more than $8 \%$ in a decade. Retrieved from https://hechingerreport.org/the-number-of-public-school-students-could-fall-bymore-than-8-in-a-decade/

Behn, B.K., Ezzell, W.F., Murphy, L.A., Rayburn, J.D., Stith, M.T., \& Strawser, J.R. (2012). The Pathways Commission on Accounting Higher Education: Charting a national strategy for the next generation of accountants. Issues in Accounting Education, 27(3), 595-600.

Chen, C., Jones, K.T., \& McIntyre, D.D. (2005). A reexamination of the factors important to selection of accounting as a major. Accounting and the Public Interest, 5(1), 14-31.

Djatej, A., Chen, Y., Eriksen, S., \& Zhou, D. (2015). Understanding students' major choice in accounting: An application of the theory of reasoned action. Global Perspectives on Accounting Education, $12,53$.

Durlak, J.A. (2009). How to select, calculate, and interpret effect sizes. Journal of Pediatric Psychology, 34(9), 917-928.

Felton, S., Dimnik, T., \& Northey, M. (1995). A theory of reasoned action model of the chartered accountant career choice. Journal of Accounting Education, 13(1), 1-19.

Ferguson, C.J. (2009). An effect size primer: A guide for clinicians and researchers. Professional Psychology: Research and Practice, 40(5), 532.

Gabbin, A.L. (2019). Warning Signs about the future supply of accounting graduates. The CPA Journal, $89(9), 10-11$.

Gabbin, A.L., Ferguson, S.Q., \& Foreman, K.A. (2019). Student perceptions of the accounting major: Is the profession's reputation falling? The CPA Journal, 89(12), 14-15.

Jacoby, C.R. (1976). The effects of teaching methods and experiences in achievement of business students in the first college level accounting course (Unpublished Doctoral Dissertation). The Pennsylvania State University. 
Jones, S.H., \& Wright, M. (2011). Effect of cognitive style on performance in introductory financial accounting and the decision to major in accounting. Global Perspectives on Accounting Education, 8, 7.

Law, P.K. (2010). A theory of reasoned action model of accounting students' career choice in public accounting practices in the post-Enron. Journal of Applied Accounting Research, 11, 58-73.

Lent, R.W., Brown, S.D., \& Hackett, G. (1994). Toward a unifying social cognitive theory of career and academic interest, choice, and performance. Journal of Vocational Behavior, 45(1), 79-122.

Lent, R.W., Brown, S.D., \& Hackett, G. (2002). Social cognitive career theory. Career Choice and Development, 4, 255-311.

Schroeder, N. (1985). The effects of pre-college accounting on the college accounting student. The Journal of Business Education, 60(5), 207-211.

Seltzer, R. (2016). The high school graduation plateau. Inside Higher Ed. Retrieved from https://www.insidehighered.com/news/2016/12/06/high-school-graduates-drop-number-and-beincreasingly-diverse\#backtotop

Smith, J.W. (1968). Articulation of high school bookkeeping and college elementary accounting (Doctoral Dissertation). Retrieved from University Microfilms, Inc., Ann Arbor, Michigan. (6814, 208).

Swanson, G., \& Brooks, L. (1984). High school bookkeeping/accounting and success in college accounting. Balance Sheet, 66(2), 4-7.

\section{APPENDIX A}

\section{Survey Instrument}

\section{Block 1}

Are you 18 years of age or older?

$\mathrm{O}$ Yes

O No

\section{Default Question Block}

Please click on the following link and read the consent form.

$\underline{\text { IRB Consent Form.pdf }}$

After reading the consent form, do you voluntarily agree to participate in this research study?

O Yes

O No 


\section{Demographic Questions}

What is your age?

O 17

O 18

O 19

○ 20

○ 21

○ 22

O 22 or older

What school do you attend?

O Georgia Gwinnett College

O Slippery Rock University

\section{What is your race?}

O Black

O White

O Latino

O Asian

O Other

What is your class standing?

O Freshman

O Sophomore

O Junior

O Senior

How many accounting courses have you taken in high school?

O 1

O 2

O More than 2

How many accounting courses have you taken in college?

O 1

O 2

O More than 2 
Are you currently majoring in Accounting?

O Yes

O No

Are you the first person from your immediate (mother, father, sisters, brothers) family to attend college?

O Yes

O No

O Do not know

Did your mother attend college?

O Yes

O No

O Do not know

Did your mother graduate from college?

O Yes

O No

Do not know

Did your father attend college?

O Yes

O No

Do not know

Did your father graduate from college?

O Yes

O No

Do not know

Do you have brothers or sisters who attended college?

O Yes

O No

Do not know 
Do you have brothers or sisters who graduated from college?

O Yes

O No

Do not know

\section{Accounting Self-Efficacy}

\begin{tabular}{|c|c|c|c|c|c|c|c|}
\hline & $\begin{array}{l}\text { Strongly } \\
\text { Disagree }\end{array}$ & Disagree & $\begin{array}{l}\text { Somewhat } \\
\text { Disagree }\end{array}$ & $\begin{array}{l}\text { Neither } \\
\text { Agree not } \\
\text { Disagree }\end{array}$ & $\begin{array}{c}\text { Somewhat } \\
\text { Agree }\end{array}$ & Agree & $\begin{array}{c}\text { Strongly } \\
\text { Agree }\end{array}$ \\
\hline $\begin{array}{l}\text { I am good at } \\
\text { analyzing and } \\
\text { solving } \\
\text { business-related } \\
\text { problems }\end{array}$ & 0 & 0 & 0 & 0 & 0 & 0 & 0 \\
\hline $\begin{array}{l}\text { I am good at } \\
\text { evaluating } \\
\text { options for } \\
\text { decision-making } \\
\text { and reaching } \\
\text { conclusions }\end{array}$ & 0 & 0 & 0 & O & 0 & 0 & 0 \\
\hline $\begin{array}{l}\text { I am usually able } \\
\text { to locate and } \\
\text { extract relevant } \\
\text { information } \\
\text { from available } \\
\text { resource } \\
\text { materials }\end{array}$ & 0 & 0 & 0 & 0 & 0 & 0 & 0 \\
\hline $\begin{array}{l}\text { I am usually able } \\
\text { to recognize and } \\
\text { comprehend the } \\
\text { meaning and } \\
\text { application of a } \\
\text { particular matter. }\end{array}$ & 0 & 0 & 0 & 0 & 0 & 0 & 0 \\
\hline
\end{tabular}


Image of the Accounting Profession: Most People working in Accounting are...

\begin{tabular}{|c|c|c|c|c|c|c|c|}
\hline & $\begin{array}{l}\text { Strongly } \\
\text { Disagree }\end{array}$ & Disagree & $\begin{array}{l}\text { Somewhat } \\
\text { Disagree }\end{array}$ & $\begin{array}{l}\text { Neither } \\
\text { Agree not } \\
\text { Disagree }\end{array}$ & $\begin{array}{c}\text { Somewhat } \\
\text { Agree }\end{array}$ & Agree & $\begin{array}{c}\text { Strongly } \\
\text { Agree }\end{array}$ \\
\hline $\begin{array}{l}\text { "Geeky" } \\
\text { and } \\
\text { "nerdy" }\end{array}$ & 0 & 0 & 0 & 0 & 0 & 0 & 0 \\
\hline $\begin{array}{l}\text { not } \\
\text { outgoing }\end{array}$ & 0 & 0 & 0 & 0 & 0 & 0 & 0 \\
\hline $\begin{array}{l}\text { boring to } \\
\text { be around }\end{array}$ & 0 & 0 & 0 & 0 & 0 & 0 & 0 \\
\hline $\begin{array}{l}\text { Lack } \\
\text { social } \\
\text { skills }\end{array}$ & 0 & 0 & 0 & 0 & 0 & 0 & 0 \\
\hline not cool & 0 & 0 & 0 & 0 & 0 & 0 & 0 \\
\hline
\end{tabular}

\section{Social Influence}

My close friends would think I should major in Accounting

My family would think that I should major in Accounting

My significant-other would think that I should major in Accounting

\section{Strongly Disagree}

○

O

○
Strongly Agree

○

○

O
Neither Agree or Disagree

○

Personal Interest in Accounting

$\begin{array}{ccccccc}\text { Bad Idea } & \begin{array}{c}\text { Moderately } \\ \text { Bad Idea }\end{array} & \begin{array}{c}\text { Slightly } \\ \text { Bad Idea }\end{array} & \begin{array}{c}\text { Neither } \\ \text { Good or } \\ \text { Bad Idea }\end{array} & \begin{array}{c}\text { Slightly } \\ \text { Good Idea }\end{array} & \begin{array}{c}\text { Moderately } \\ \text { Good Idea }\end{array} & \begin{array}{c}\text { Good } \\ \text { Idea }\end{array} \\ & & & \end{array}$

For me to major in accounting would be a

O
○

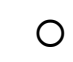


Personal Interest in Accounting

$\begin{array}{llccccc}\text { Unpleasant } & \begin{array}{c}\text { Moderately } \\ \text { Unpleasant }\end{array} & \begin{array}{c}\text { Slightly } \\ \text { Unpleasant }\end{array} & \begin{array}{c}\text { Neither } \\ \text { Pleasant or } \\ \text { Unpleasant }\end{array} & \begin{array}{c}\text { Slightly } \\ \text { Pleasant }\end{array} & \begin{array}{c}\text { Moderately } \\ \text { Pleasant }\end{array} & \begin{array}{c}\text { Good } \\ \text { Pleasant }\end{array} \\ \text { For me to } & & & \text { Unas } & & \end{array}$

For me to

major in

accounting

would be a

○

O

$\bigcirc$

Intent to Major in Accounting

$\begin{array}{ccccccc}\text { Unpleasant } & \text { Moderately } & \text { Slightly } & \text { Neither } & \text { Slightly } & \text { Moderately } & \text { Good } \\ & \text { Unpleasant } & \text { Unpleasant } & \text { Pleasant or } & \text { Pleasant } & \text { Pleasant } & \text { Pleasant } \\ \text { Unpleasant } & & & \end{array}$

Assuming I

satisfy the

requirements

to major in

Accounting,

I intend/plan

to major in

Accounting

Block 2

Do you want to enter your email address for participation in random drawing for small-dollar gift card?

O Yes

O No

What is your email address? 


\section{APPENDIX B}

\section{FOCUS GROUP INTERVIEW PROTOCOL}

1. Opening Script - thank you for agreeing to participate in this focus group on high school or college student interest in Accounting. I appreciate your participation in this voluntary and confidential discussion. Please note that this discussion will be recorded for research purposes, but I've put several measures in place to ensure your anonymity.

2. First, none of you will be referred to you by your actual names, which is why I've given you each name-tags with monikers instead of your real names.

3. Second, I ask that you avoid using the name of your school.

4. Third, my research protocol has been reviewed and approved by the Slippery Rock University Institutional Review Board, which protects your rights and privacy as participants of this research.

5. This discussion will be divided into three sections.

a. First, I must obtain your assent or consent (voluntary cooperation) to participate in the research study.

b. Second, if you agree to participate in the study, I will ask you to take a brief demographic survey.

c. Third, I will ask questions about your experience with accounting work and knowledge of the accounting profession.

6. 2-3 minutes for survey.

7. Focus group discussion: Now that you have answered the demographic questionnaire, let's discuss your level of interest in accounting, general knowledge about the accounting profession, and your experiences with accounting work.

a. Why did you choose to take an accounting course in high school?

b. What career opportunities are available in the accounting profession?

c. What skills do you need to be an accountant?

d. What are the educational requirements to become a professional accountant?

e. Do you want to be a professional accountant and if so, why?

f. Is there anything preventing you from majoring in accounting?

g. Do you know any professional accountants and if so, what is their relationship to you?

h. Do you currently operate your own business or do you want to own business?

i. What is your perception of an accountant?

j. What do you plan to major in and why?

k. What influenced you to consider a career in accounting? 
TABLE C1

DESCRIPTIVE STATISTICS AND CORRELATIONS

\begin{tabular}{lccccc}
\hline \multicolumn{1}{c}{ Variable } & Mean & SD & 1 & 2 & 3 \\
1. Personal Interest in Accounting & 4.15 & 1.80 & - & & \\
2. Accounting Technical Skills Self-efficacy & 5.43 & 1.01 & $.33^{* *}$ & - & \\
3. Image of the Accounting Profession & 5.13 & 1.33 & -.04 & .98 & - \\
4. Intent to Major & 3.37 & 2.25 & $.75^{* *}$ & .29 & .03 \\
\hline Note: $N=150 .{ }^{*} p<.05,{ }^{* *} p<.01$ & & & &
\end{tabular}

TABLE C2

PERSONAL INTEREST: $t$-TEST RESULTS AND EFFECT SIZES

\begin{tabular}{lcccccc}
\hline & $\begin{array}{c}\text { High } \\
\text { School } \\
\text { Accounting }\end{array}$ & $N$ & & & & \multicolumn{2}{c}{$\begin{array}{c}\text { 2- Tailed } \\
\text { Significance }\end{array}$} & $\begin{array}{c}\text { Effect } \\
\text { Size } \\
\text { Cohen's } d\end{array}$ \\
\hline 1 Freshmen & No & 41 & 3.67 & -2.29 & .03 & -.56 \\
2 Freshmen & Yes & 27 & 4.69 & & & \\
& & & & & & \\
3 Sophomores & No & 55 & 3.98 & -1.66 & .10 & -.37 \\
4 Sophomores & Yes & 27 & 4.67 & & & \\
& & & & & & \\
5 Freshmen and Sophomores & No & 96 & 3.85 & -2.75 & .01 & -.45 \\
6 Freshmen and Sophomores & Yes & 54 & 4.68 & & & \\
\hline
\end{tabular}

TABLE C3

ACCOUNTING TECHNICAL SKILLS SELF-EFFICACY: t-TEST RESULTS AND EFFECT SIZES

\begin{tabular}{lcccccc}
\hline & $\begin{array}{c}\text { High } \\
\text { School } \\
\text { Accounting }\end{array}$ & $N$ & Mean & t & $\begin{array}{c}\text { 2- Tailed } \\
\text { Significance }\end{array}$ & $\begin{array}{c}\text { Effect } \\
\text { Size } \\
\text { Cohen's } d\end{array}$ \\
\hline 1 Freshmen & No & 41 & 5.15 & -1.93 & .06 & -.47 \\
2 Freshmen & Yes & 27 & 5.65 & & & \\
3 Sophomores & & & & & & .26 \\
4 Sophomores & No & 55 & 5.58 & 1.18 & .24 & \\
& Yes & 27 & 5.31 & & & \\
5 Freshmen and Sophomores & No & 96 & 5.39 & -.51 & .61 & -.08 \\
6 Freshmen and Sophomores & Yes & 54 & 5.48 & & & \\
\hline
\end{tabular}


TABLE C4

IMAGE OF THE ACCOUNTING PROFESSION: t-TEST RESULTS AND EFFECT SIZES

\begin{tabular}{|c|c|c|c|c|c|c|}
\hline Group & $\begin{array}{c}\text { High } \\
\text { School } \\
\text { Accounting }\end{array}$ & $N$ & Mean & $\mathrm{t}$ & $\begin{array}{c}2 \text { - Tailed } \\
\text { Significance }\end{array}$ & $\begin{array}{c}\text { Effect } \\
\text { Size } \\
\text { Cohen's } d\end{array}$ \\
\hline 1 Freshmen & No & 41 & 5.22 & .51 & .62 & .12 \\
\hline 2 Freshmen & Yes & 27 & 5.04 & & & \\
\hline 3 Sophomores & No & 55 & 5.20 & .82 & .42 & .18 \\
\hline 4 Sophomores & Yes & 27 & 4.96 & & & \\
\hline 5 Freshmen and Sophomores & No & 96 & 5.21 & .92 & .36 & .15 \\
\hline 6 Freshmen and Sophomores & Yes & 54 & 5.00 & & & \\
\hline
\end{tabular}

TABLE C5

INTENT TO MAJOR IN ACCOUNTING: t-TEST RESULTS AND EFFECT SIZES

\begin{tabular}{|c|c|c|c|c|c|c|}
\hline Group & $\begin{array}{c}\text { High } \\
\text { School } \\
\text { Accounting }\end{array}$ & $N$ & Mean & $\mathrm{t}$ & $\begin{array}{c}2 \text { - Tailed } \\
\text { Significance }\end{array}$ & $\begin{array}{l}\text { Effect Size } \\
\text { Cohen's } d\end{array}$ \\
\hline 1 Freshmen & No & 41 & 2.93 & -1.47 & .15 & -.36 \\
\hline 2 Freshmen & Yes & 27 & 3.70 & & & \\
\hline 3 Sophomores & No & 55 & 3.09 & -2.18 & .03 & -.49 \\
\hline 4 Sophomores & Yes & 27 & 4.26 & & & \\
\hline 5 Freshmen and Sophomores & No & 96 & 3.02 & -2.56 & .01 & -.42 \\
\hline 6 Freshmen and Sophomores & Yes & 54 & 3.98 & & & \\
\hline
\end{tabular}

